\title{
The Implemetation Of One Village, One Product (Ovop) Program In Banda Aceh City
}

\author{
Fanny Nailufar ${ }^{1}$ and Sufitrayati ${ }^{1}$ \\ \{fanny.nailufar@serambimekkah.ac.id,sufitrayati@serambimekkah.ac.id\} \\ ${ }^{1}$ Department of Economic, Serambi Mekkah University, Banda Aceh, Aceh, Indonesia
}

\begin{abstract}
The purpose of this research was to find out how to implement the One Village, One Product (OVOP) Program in the Village Featured Product Business Unit in Banda Aceh city. The data used in this study were secondary data which was sourced from the Central Bureau of Statistics (BPS), the Office of Industry, Trade, Cooperatives and Small and Medium Enterprises (UKM) of Banda Aceh city, the Department of Manpower and Population of the Aceh Province, Development Task Force Creative Economy (TF Ekraf) Banda Aceh city and other relevant institutions. Respondents in this study were policy makers from various institutions and several actors who were tasked with planning, designing and implementing OVOP programs in Banda Aceh city. This study was analysed using qualitative methods by analysing the findings data and conducting interviews that were quite in-depth to the respondents. The results of this study indicated that the implementation of the OVOP program in the Banda Aceh city has gone through several stages in accordance with the criteria for the development of MSMEs with the OVOP approach set by the Ministry of Industry of the Republic of Indonesia. Some coaching instruments were not maximally implemented such as assistance in business facilities and capital facilities. This was inseparable from the lack of funds allocated to this OVOP program. By mapping MSME products and establishing OVOP products, they contributed greatly to the development of MSMEs in Banda Aceh city.
\end{abstract}

Keywords: One Village One Product, Female Workers, Featured Products

\section{Introduction}

The development of Micro, Small and Medium Enterprises (MSMEs) in Banda Aceh City is a very strategic target in increasing regional economic growth. Various policy instruments are reviewed and applied to make a real contribution in improving the economy of small and medium-sized communities in Banda Aceh City. Various potential of featured products have also emerged with all forms of innovation, creativity and management strategies that have become the competitiveness of these featured products. The Office of Industry, Trade and Cooperatives (Disperindagkop) of Banda Aceh City as a government institution has a very large contribution in implementing featured programs for the sustainability of various forms of industrial businesses in Banda Aceh City. This is a very important factor considering that the industrial business requires various forms of assistance and intensive guidance to achieve goals in alleviating regional poverty and reducing the number of unemployed people in Banda Aceh City. 
The One Village One Product (OVOP) program is one of the creative economic development programs that became the initial focus for the Banda Aceh City Government through the Banda Aceh City Office of Industry, Trade and Cooperatives (Disperindagkop). The program, which began in 2016, was launched so that every village is able to take advantage of the local potential of the region. The program was also implemented to answer the high rate of unemployment and poverty in Banda Aceh City. Various business groups are given guidance by involving various cross-sectors in the scope of the Aceh government. In accordance with Presidential Instruction No. 6 of 2007 concerning the Policy of Accelerating Real Sector Development and Empowerment of Micro, Small and Medium Enterprises, assigns tasks to all Ministers, Heads of Non-Departmental Government Agencies, Governors and Regents / Mayors to take necessary steps according to their duties, functions and authorities each. The Ministry of Industry has taken policy steps with the issuance of the Minister of Industry Regulation Number 78 / M-IND / PER / 2007 concerning Increasing the Effectiveness of the Development of Small and Medium Industries through the One Village One Product Approach (One Village One Product) at the centre.

The One Village One Product (OVOP) program was launched in Banda City with the aim of reducing unemployment and poverty in Banda Aceh City. Banda Aceh's Office of Industry, Trade and Cooperatives (Disperindagkop) provides various training and assistance in the form of raw materials which are considered more effective than cash assistance for various small and medium industries. This program has formed a target group of almost 200 groups from 90 Gampong (Villages) in Banda Aceh City. Every village has potential, creative and innovative human resources to process a product, developed and sold as a quality processed product. Although marketing problems become obstacles in selling products, an effective promotional activity is needed. Therefore, assistance is needed in marketing the superior products of a village. So that by itself the gampong featured products can be easily marketed both within the Banda Aceh City area and outside the Banda Aceh City. Initial data that has been successfully mapped by the Open Data Labs Jakarta and International Conference on Aceh and Indian Ocean Studies (ICAIOS), in Banda Aceh, there are 368 products from the One Village One Product (OVOP) program in Gampong that have been driven by City government. The data which are mapped and included in the Tanyoe Produk group (our products) is around 140 village featured products. This program produced various business units which became the focus of the OVOP program and began to develop very rapidly. It attracts many female workers who also join the business unit. This certainly will have a positive impact on the economy of women working in OVOP-assisted businesses. It can even open jobs opportunity for the surrounding community.

\section{Methodology}

\subsection{One Village One Product (OVOP)}

The One Village One Product (OVOP) approach was developed by Morihiko Hiramatsu, a former MITI official who was elected as Governor of Oita in 1979. His position at Oita for 6 periods (1979-2003) was used as well as possible to alleviate the poverty of its citizens by implementing the idea of regional development concepts and developing regional potential by involving community leaders, and the community itself so that they are motivated to rise up and build their regions into prosperous areas and prosper the community [1]. 
The OVOP approach was first introduced and started by rural communities in Oita Prefecture, Japan. This self-growing community movement has been very successful in increasing Japan's per capita income to double in two decades. This success later became an example for a number of countries to develop the potential of regions with similar patterns [2].Some countries that have succeeded in developing it are Thailand (One Tambon One Product), Taiwan (One Town One Product), Malaysia (One District One Industry), Philippines (One Town One Product), and Cambodia (One Village One Product) (Triharini et al., 2012). In Thailand, One Tambon One Product (OTOP) which was introduced by the Thai government since 2001 and fully implemented in 2002 was successfully implemented because the OTOP program was based on the strong desire of various elements of the community to work together with the government to get better benefits. Although there are some shortcomings in the implementation of the OTOP program, overall the OTOP program has helped many rural families and have been able to reduce poverty and improve the quality of life of the community [3]

\subsection{One Village One Product in Indonesia}

In Indonesia, the OVOP approach was initiated in 2006 by the Ministry of Industry which was then marked by the issuance of Presidential Instruction No. 6/2007 concerning the policy of accelerating the development of the real sector and the empowerment of Micro, Small and Medium Enterprises (MSMEs) and Regulation of the Minister of Industry No. 78 / M-Ind / Per / 9/2007 concerning increasing the effectiveness of the development of Small and Medium Industries (UMKM) through the One Village One Product (OVOP) approach that interrelates to encourage small and medium-sized local industrial products to be able to compete in the global market (Pasaribu et al., 2011). Furthermore, the Ministry of Cooperatives and Small and Medium Enterprises (SMEs) followed it for about five years. The economic activities with the OVOP approach seem to be running independently by the Ministry of Industry and the Ministry of Cooperatives and SMEs, although they are said to be coordinated with the Ministry of Trade, Ministry of Home Affairs and government in various regions. Unexpectedly, the Ministry of Agriculture did not take part in the development of agroindustry with the OVOP approach, although many small industrial products were produced based on agricultural production. Therefore, the Ministry of Agriculture needs to take strategic policies by incorporating the OVOP approach in the development of agro-industry in rural areas [4].

The definition of OVOP in Indonesia from the Deputy Minister of SMEs and Resource Research at the Ministry of Cooperatives and SMEs of the Republic of Indonesia is an effort by the government to increase the added value of regional featured products in order to improve the welfare of the community in cooperatives or SMEs. According to Prayudi (2008), there are three backgrounds of the emergence of OVOP: first, the existence of concentrations and population densities in cities as a result of patterns of urbanization and lead to a decline in the rural population. Second, to be able to revive the movement and economic growth in the countryside, it is necessary to generate a wheel of economic activity that is in accordance with the scale and size of the countryside by utilizing the potential and capabilities of the village and involving local community leaders. Third, reducing the dependence of village communities that are too high for the regional government and the central government.

\subsection{One Village One Product Concept in Indonesia}

The three principles of the OVOP movement, namely: local but global, which means the development of the OVOP approach aims to improve, develop and market products that can 
be a source of pride for the local community. Especially those that can be marketed both inside and outside the country. So that local but global goals are achieved. Independence and creativity so that people can rise up and be creative. The last is the development of human resources, namely the regional government [1].

OVOP is a community movement that integrally increase public awareness of the potential and wealth of the region, increase the income of business people and the community, and at the same time increase confidence and pride in the capabilities of the community and the region. Natural resources or local cultural products and local specialty products that have been carried out for generations can be extracted and developed to produce high value-added products according to market demands. With the clear division of roles of each stakeholder, the existence of good planning, the existence of stages of activities and a joint commitment of stakeholders to strengthen MSMEs in the country, increasing the effectiveness of MSME development through the OVOP approach at the centre is expected to be achieved (Badruddin, 2011) .

\subsection{Research Site}

The research was carried out in the city of Banda Aceh, which is the capital of Aceh Province. This study discussed the OVOP implementation process in Banda Aceh City. The discussion of this research was only limited to the One Village program, One Product (OVOP) in the village featured product business unit in Banda Aceh City.

\subsection{Research Design}

The study was conducted in the Banda Aceh City. The study was conducted quantitatively with a descriptive research design. Descriptive design was aimed to explain something, such as: explaining the characteristics of a relevant group, estimating the percentage of nuclei in a particular population that shows certain behaviours, knowing perceptions of product characteristics, knowing how much a variable relates and to find specific predictions [5]. In this study, researchers wanted to analyse the implementation of the One Village One Product (OVOP) program of the village featured product business in Banda Aceh City. which is the Capital of Aceh Province. This study discussed the OVOP implementation process in Banda Aceh City. The discussion of this research was only limited to the One Village program, One Product $(\mathrm{OVOP})$ in the village featured product business unit in Banda Aceh City.

\section{Result And Discussion}

\subsection{One Village One Product (OVOP) in Banda Aceh City}

Banda Aceh as one of the cities incorporated in the network of Creative Indonesia cities has a strategic role to develop a creativity-based community economy with an inclusive touch of science. Creative economic development is one of the right choices for improving the welfare of urban communities such as Banda Aceh. As a region that has limitations on natural resources of agriculture, plantations and livestock, the economy that intensifies the use of information and creativity by relying on ideas and the stock of knowledge from human resources is an important alternative to the economic development of communities in Banda Aceh. This creative economy will help create a positive business climate based on renewable resources with competitive innovations that can enhance the image and identity of the 
Indonesian nation. Collaboration by the Banda Aceh City Government through the Department of Industry, Trade and Cooperatives (Disperindagkop) with the University of Syiah Kuala through the Centre for Keratif Industry at the Syiah Kuala University or the Centre for Creative Industry of Syiah Kuala University (CCIS) is a strategic step to involve science from the university in the process of development and economic development of the community. In its implementation, the Banda Aceh city government has formed the Banda Aceh Creative Economy Development Task Force (TF) involving elements from the government, universities, businesses and communities. The synergy of the four elements known as the Quadro Helix Approach is believed to produce a strong movement and impact in the development of the creative economy of Banda Aceh City.

From the beginning of 2016, TF Ekraf has developed various creative economy development programs in Banda Aceh City, with an initial focus on the One Village One Product (OVOP) program. TF Ekraf in collaboration with the International Centre for Aceh and Indian Ocean Studies (ICAIOS) has sent enumerators to 90 villages in the city of Banda Aceh to conduct surveys on Micro, Small and Medium Enterprises (MSME) products and found around 368 MSMEs.

From the 368 MSMEs found, TF Ekraf Kota Banda Aceh has determined 116 MSMEs that are considered creative and innovative that will strengthen the city of Banda Aceh as the only city in Aceh that has entered the network of creative cities in Indonesia. A total of 116 MSMEs were selected based on certain criteria in accordance with the provisions set by the Ministry of Industry of the Republic of Indonesia. Based on the selection of 116 creative and innovative MSMEs, TF Ekraf of Banda Aceh City then intervened in various star enhancement product of coaching programs in 2017 in the form of strengthening building capacity, improving product quality and certification, mentoring programs, providing incentives and expanding markets in accordance with budget availability. It is expected that this creative economic development program can continue in the future until it can have a meaningful impact on improving the welfare of the community, especially in Banda Aceh City.

\subsection{Programme Implementation of One Village One Product (OVOP) in Banda Aceh}

Based on the results of an open interview with the Chairman of the Creative Economy Task Force Banda Aceh, Dr. Syaifullah Muhammad, ST, M. Eng explained that the OVOP program was initiated since 2007 by the Mayor of Banda Aceh at the time, Ms. Illiza Sa'adudin Djamal. However, the sustainability of the program can only be realized in 2016 with the issuance of the Banda Aceh Mayor Decree No. 355/2016 regarding the Establishment of the Regional Featured Product Development Plan Document for Banda Aceh City and the Decree of the Head of the Banda Aceh City of Industry, Trade, Cooperatives and SMEs No. 35/2016 concerning the Establishment of the Banda Aceh Micro, Small and Medium Business Enumerator Team and formed the Banda Aceh City Creative Economic Development Task Force (TF) involving elements of government, universities, businesses and communities / society. The stages of implementing the OVOP program in Banda Aceh are:

1. Agreement on the signing of the MoU between the Banda Aceh City Government through the Department of Industry, Trade and Cooperatives (Disperindagkop) with Syiah Kuala University through the Centre for Keratif Industry at the Syiah Kula University or Centre for Creative Industry of Syiah Kuala University (CCIS)

2. Establishment of the Creative Economy Task Force Team (TF Ekraf) in Banda Aceh City

3. Conducting a survey mapping of the products of the UMKM creative industry in Banda Aceh (OVOP Survey) 
4. Preparation and Launching of the Banda Aceh 90 Gampong MSME Product Catalogue in 2016

5. Conducting an assessment and classification of OVOP products in accordance with the criteria set by the Ministry of Industry of the Republic of Indonesia.

6. Selection of 116 OVOP products and conducting training with various instruments such as:

1)Training

2)Assistance to experts

3)Promotions, exhibitions and expos

4)Providing incentives

7. Establish 3 featured village products according to the assessment criteria. The 3 products are:

1) Coffee Products (Ulee Kareng)

2) Fish Products (Lampulo)

3) Craft Products (Lambaro Skep)

8. In 2018, TF Ekraf Kota Banda Aceh will conduct guidance to improve the quality of OVOP products from 2 stars to 1 star

9. TF Ekraf Kota Banda Aceh will try to facilitate OVOP products by building a showroom for promotional activities, exhibitions and product expos.

10. In 2019, TF Ekraf Kota Banda Aceh will carry out advanced market quality control for OVOP products.

\section{Conclusion}

1. The implementation of OVOP in the city of Banda Aceh has gone through several stages in accordance with the criteria for the development of MSMEs with the OVOP approach set by the Ministry of Industry of the Republic of Indonesia.

2. Some guidance instruments are not maximally implemented such as business facilities and capital facilities. This is inseparable from the lack of funds allocated for this OVOP program.

3. By mapping MSME products and determining OVOP products contribute greatly to the development of MSMEs in Banda Aceh City

\section{References}

[1] R. R. Cahyani, "Approach to One Village One Product (OVOP) to Improve UMKM Creativity and Community Welfare," Sustain. Compet. Advant., vol. 3, no. `, 2013.

[2] S. Maryanti, "Movement One Village One Product (OVOP): One Nagari One Product Movement." Jakarta, 2011.

[3] R. Badrudin, "Development Model of Micro, Small and Medium Enterprises with One Village One Product for Reducing Poverty in Indonesia," J. Account. Manag., vol. 22, no. 11, pp. 39-66, 2011.

[4] Nurcahyo, Rahmat, Farizal, E. Setiadi, and Saparudin, "Determination and Development of Core Competencies in Bekasi Regency," J. Ind. Eng., vol. 13, no. 1, pp. 37-42, 2012.

[5] Malhotra, Research methods. Jakarta: Ghalia Indonesia, 2007.

[6] Hasibuan, M.S.P. (2007). Development Economy and the Indonesian Economy. CV. Armico. Bandung. 
[7] Patrisina, Reinny and Beni Harma, (2011), "Analysis of Technical and Financial

Aspects of Establishment of Distribution Centres for One Village One Product Program (OVOP): Case Study of Agam Embroidery / Embroidery", Journal of Industrial Engineering, Vol. 9, No. 1: 1-24.

[8] Poerwono, Hadi. (2014). Personnel Management, Issue 3, Faculty of Economics, Gajah Mada University. Yogyakarta.

[9] Simanjuntak, Payaman J (2008). Introduction to Human Resource Economics. LP3ES. Jakarta. 